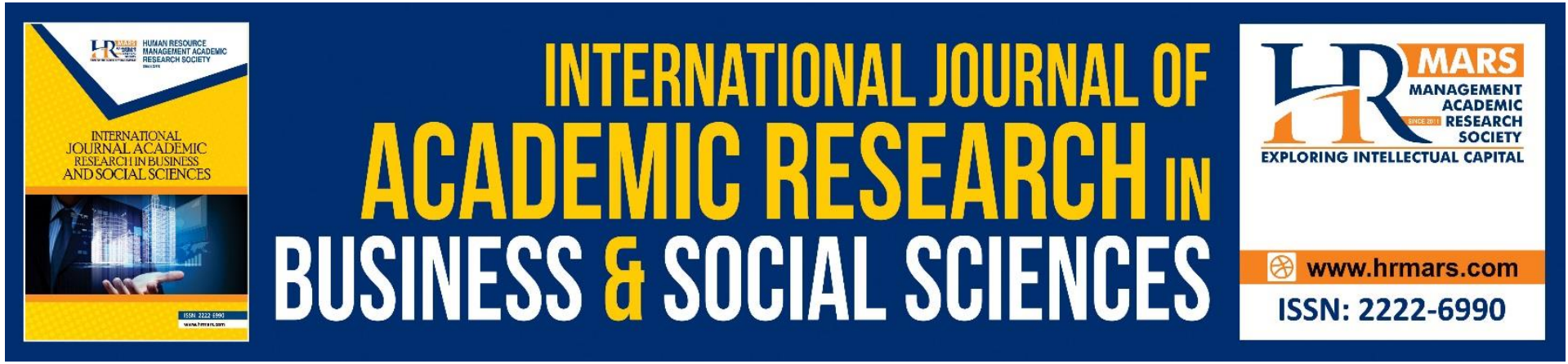

\title{
Listening Strategies in An Instructed Classroom Setting Used by Year 4 Pupils to Enhance ESL Listening Skills
}

Dasinta Seladorai, Dheventhiran Dass, Girija Wathumalai, Mathura Kasiveloo, Priyadharishini Ponnaiah \& Harwati Hashim

To Link this Article: http://dx.doi.org/10.6007/IJARBSS/v11-i6/10052 DOI:10.6007/IJARBSS/v11-i6/10052

Received: 25 April 2021, Revised: 28 May 2021, Accepted: 12 June 2021

Published Online: 27 June 2021

In-Text Citation: (Seladorai et al., 2021)

To Cite this Article: Seladorai, D., Dass, D., Wathumalai, G., Kasiveloo, M., Ponnaiah, P., \& Hashim, H. (2021). Listening Strategies in An Instructed Classroom Setting Used by Year 4 Pupils to Enhance ESL Listening Skills. International Journal of Academic Research in Business and Social Sciences, 11(6), 1688-1701.

Copyright: (c) 2021 The Author(s)

Published by Human Resource Management Academic Research Society (www.hrmars.com)

This article is published under the Creative Commons Attribution (CC BY 4.0) license. Anyone may reproduce, distribute, translate and create derivative works of this article (for both commercial and non-commercial purposes), subject to full attribution to the original publication and authors. The full terms of this license may be seen

at: http://creativecommons.org/licences/by/4.0/legalcode

Vol. 11, No. 6, 2021, Pg. 1688 - 1701

http://hrmars.com/index.php/pages/detail/IJARBSS

JOURNAL HOMEPAGE

Full Terms \& Conditions of access and use can be found at http://hrmars.com/index.php/pages/detail/publication-ethics 


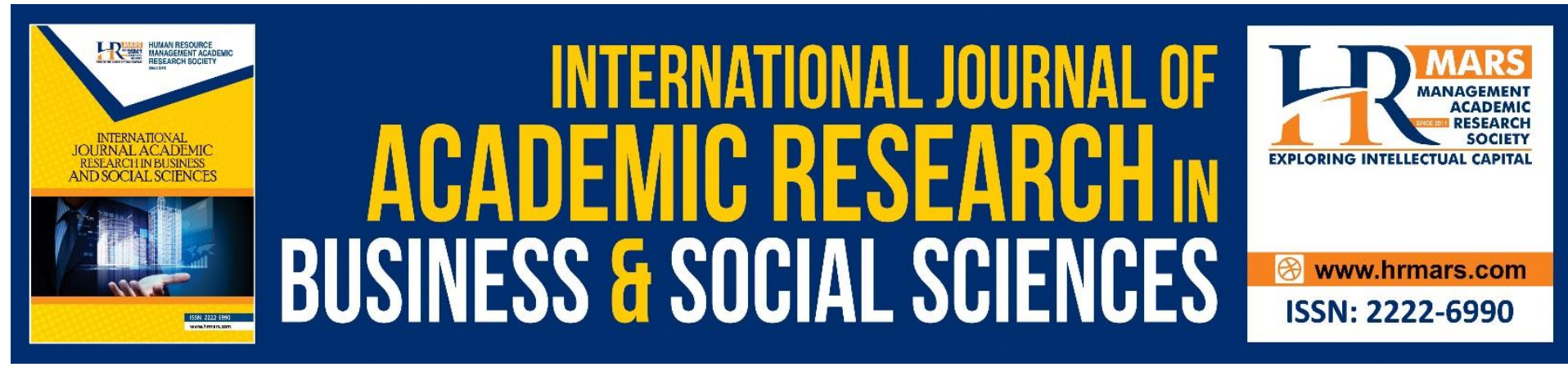

\title{
Listening Strategies in An Instructed Classroom Setting Used by Year 4 Pupils to Enhance ESL Listening Skills
}

\author{
Dasinta Seladorai, Dheventhiran Dass, Girija Wathumalai, \\ Mathura Kasiveloo, Priyadharishini Ponnaiah \& Harwati Hashim \\ Univerisiti Kebangsaan Malaysia(UKM), 43600 Bangi, Selangor, Malaysia \\ Email: dasintaseladorai@gmail.com
}

\begin{abstract}
All four language skills are a child's solution to the puzzle of learning. While all skills are crucial for language learning, this study accentuates learning strategies used in an instructed classroom setting by Year 4 pupils to enhance ESL listening skills. Six-language learning strategies namely memory, cognitive, compensation, meta cognitive, affective and social were proposed in this study. Thirty pupils from an intermediate class were chosen to participate in this study. A purposive sampling was done to select participants from a suburban area. A Strategy Inventory of Language Learning (SILL) questionnaire and a checklist were used to collect data. The study procured that the most common strategy used by the participants with the highest mean score was the social strategy. The findings showed that participants tend to use social strategy through the interaction among peers in classroom. This research concludes with call for more research into this promising pedagogy.
\end{abstract}

Keywords: listening Skill, Listening Strategies, Instructed Classroom Setting, ESL, Strategy Inventory of Language Learning (SILL).

\section{Introduction}

The English language curriculum under the Common European Framework of References for Languages (CEFR) aims to equip pupils with basic language skills such as listening and speaking skills, reading skills, writing skills, grammar and language arts to enable them to communicate effectively in a variety of contexts that's appropriate to the pupils' level of development. According to Vernier (2008), acquiring all four primary language skills are equivalently dominant in acquiring the English language. The curriculum encompasses content standards, learning standards, integration of language skills, three broad areas of themes to be taught and educational emphases (Uni \& Abd Aziz 2018). The curriculum specifically encircles five language skills that has been redesigned and incorporated. There are listening and speaking skills, reading skills, writing skills, grammar and language arts.

According to the website "Lingua Core" in 2019, listening skill, a receptive skill is the first language skill acquired in the English language. Moreover, it is the first natural language skill that is required among English language speakers. Johar \& Abdul Aziz (2019) claims that the Common European Framework of Reference stresses on improving young learners receptive 
and productive skills. This highlights the importance of practicing teaching listening in classrooms. Hashim, Md.Yunus \& Hashim states that, educators exposing pupils to the use of learning strategies on their own in classrooms will improve their language acquiring. Djabborova (2020) in her recent study entitled Ways of developing listening skills of English learners in ESL and EFL classroom claims that pupils listening behaviors can be adjusted and molded by effective instructors in classroom with a set of strategies and approaches to each listening situation given. The researcher did list out three main types of listening activities which were pre-listening activities, while-listening activities and post-listening activities. Each one type of listening activity described the context, difficulty stage and relevance to be practiced in classroom. Practitioners are expected to understand and expose pupils to listening situations that can help them improve language learning.

In addition, the development of listening skills can be strengthened or enhanced by exposing learning strategies in classrooms. The act of not exposing pupils to the learning strategies can slow down the process as Graham, Santos \& Francis-Brophy (2014) argues that

1. Without instruction in how to improve listening, learners are very slow to develop effective listening strategy use, if at all; by contrast, it is possible to develop that effective use through instruction, with potential benefits for learners' listening proficiency.

2. The development of meta cognitive strategies and meta cognitive awareness in relation to listening can be particularly helpful and can be achieved through learner discussion of strategy use.

3. Attention to the development of bottom-up and top-down strategies is important for helping learners to develop their listening.

4. Prediction/pre-listening strategies need to be combined with strategies for verifying and monitoring predictions.

This clearly highlights that teacher are expected to expose and cultivate the use of learning strategies to assess and reassure pupils' potential as well as progress. This will aid pupils to improve their weakness in language learning on their own with the right amount of guidance from the teacher. To conclude, this clearly explains that learning strategies in an instructed classroom is a must and will definitely aid in enhancing and strengthening pupils listening skill. Therefore, this study draws the attention to the learning strategies used in an instructed classroom setting used by year four pupils to enhance their listening skills.

\section{Literature Review \\ Language Learning Strategy}

Language learning strategies (LLS) are styles or techniques utilized by the educators to teach their learners. Kasma Suwaranak (2019) stated that learning strategies are applied in the classroom to identify the mechanisms, actions and behaviours that could help learners to attain or achieve the language learning goals. She added that learning strategies are actually psychological procedues of respective learners for achieving cognitive contents. However, one needs to understand the differences between learning strategies and a language learning strategy, as they are two different domains where the first one acts as a technique for overall learning process, whereby the LLS acts as guidance for learning English language. The purpose of LLS in a learning process is to ensure that the learners are attaining their goals with their prefered techniques or styles. Just as mentioned by Oxford (2017) that language learning 
strategy could be pratical or unpractical, could be tranfered to diverse activities or learning contexts, and could be set up differently according to a variety of factors. The neccessity of teaching a spectrum of methods and strategies are vital to keep the learning process moving actively. This will enable the learners to be aware of their needed strategy in a particular learning phase to achieve their learning goals (Koksal \& Ulum, 2016). In an investigation carried out by Riri Fauzana (2016), she examined the effectiveness of learning listening strategies and the types of strategies used for effective and less effective learners from English Department students. She analyzed on the frequency of a particular strategy by using 23 strategy items from the Strategy Inventory for Language Learning (SILL). The results showed that most of them were generally strategic listeners and it actually reduced the marks of their listening comprehension cause most of the listeners actually should rely on the memory strategies. The study actually acted as a guidance and realization to the educators to choose the suitable language learning strategy pertaining to the learners ability to reach their learning goals.

\section{Listening Skill \\ Definition}

Listening skill is one of the most essential parts of language development. Listening has an important role both academically and in daily life as it is vital for people to sustain effective communication (Yildrim \& Yildrim, 2016). On the other hand, Pourhosein \& Sabouri (2016), mentioned that listening is an active mental ability that can help one to understand the world around us and is one of the necessary parts in making successful communication. Listening is the process of hearing, recognizing, interpreting, or comprehending a language. To be a productive language learner or a good communicator, listening plays an integral part where one should truly acquire. The definition of listening may differ from one researcher to another but the strength of standing against its importance remains the same. Feruza \& Matluba (2021) define listening as the basis of speaking, writing, and reading skills. They also mentioned that active listening occurs when strong continual participation is given to the listening input that one is listening to. Listening involves many aspects such as interpersonal and interpretive modes of communication, various level of colloquialism, the reduced form of language, and variable rates of delivery (Feruza \& Matluba, 2021). Meanwhile, Tri (2017) stated that listening is the cornerstone of speaking and writing. He added by saying listening can enable learners to acquire decent pronunciation and learn many useful words, phrases, and sentences in a particular language that provides enough knowledge for a learners' language acquisition. In another study conducted by Shimma (2017), listening comprehension is necessary to assist learners to make the transition from classroom language to real language more easily and effectively. Listening plays a critical role in general communication which will pursue in the future for daily live communication especially in working fields.

\section{Instructed Classroom Setting}

Instructed classroom or also known as a classroom with instructions is a purposeful method or direction aligned with planning and management that needs to be carried out for a wellversed learning process occurrence. Generally, instructions are understood as the delivery of knowledge or information by the dominant of certain subject matter and received by the controlled group. Random (2016) stated the term 'instruction' is derived from the late Middle English word instruccion which means to provide structure and direction. In a classroom, educators act as the instructors as they provide direction or guidance to the learners. An 
instructional practice should be executed to form an effective classroom setting. An instructed classroom has no designation to be implemented in a teaching and learning process. It solely depends on the plan, management, belief, and preference of the educator itself as leaders might influence student learning in many paths, but only a few make a significant difference for student achievement growth (James, Elaine \& Huang, 2016). An educator is responsible for designing suitable instructions for a classroom about the current curriculum, standard, learners' level, and interest. In a study, Charlotte and Marcel (2020) have mentioned self-regulated study as a key competency for lifelong learning that learners should acquire from early schooling. This strategy was inclusive of all subjects and skills. Veenman (2017) has referred to self-regulated learning as learners' planned, controlled, and monitored learning to make their learning more effective. This is a line that an instructed classroom has no boundaries in the learning process if it directs the learners systematically to achieve their goals. In another study, a process called schemata has been structured in a classroom for guiding the listening comprehension process. Three processes have been included in schemata which was the bottom-up, top-down, and interactive process. The results of the study showed that suitable instruction in listening comprehension can provide a good basis for developing learners who can use the listening process for learning independently and successfully control their learning behavior towards listening activities (Abbas \& Narjes, 2016).

\section{The Importance of Listening Skill in an ESL/EFL Classroom}

Listening skill is vital to be acquired by primary learners in an ESL classroom as it is one of the main skills in learning a language. The importance is propounded when it is mentioned at the first out of all the four skills. In a past study, Farah (2017) focused on the nature of the issues and challenges faced by the learners when they listen to English by exploring the status of listening skills in a classroom among Saudi Learners and the attitudes of the teachers and learners. The results were profound by the respondents' feedback where the teaching and learning process occurred following the pattern of writing, speaking, and listening. Meanwhile, teaching a language should mostly follow the pattern of reading, speaking, and writing in general. Listening skill was acquired passively by the learners, but teachers of the classroom responded that it should not be overly stressed in the classroom. The study resulted that two processes were implemented which were top-down and bottom-up. Topdown was an effective process for the respondents as repetitive lessons and prior knowledge were utilized by the learners to acquire listening skills. Teachers or educators think that practicing or miming certain culture would enable the learners to acquire a language. Reading and writing are believed that can be acquired if it is done repetitively. However, the truth befalls that a repetitive act only allows learners to memorize the techniques but not understanding the language. In another study, Khaled \& Hussam (2020) suggested three active learning activities, using role-play, language games, and technology to encourage and motivate learners towards listening skills. The importance of implementing the activities in the classroom to increase learners' motivation shows the importance given by the researcher towards the development of listening skills. The results show that implementing these activities has brought a positive impact to the learners' attitude towards learning listening skills. Therefore, this study encourages educators to implement suitable or motivating activities in the classroom to help change learners' attitudes towards the importance of acquiring listening skills. In the end, it reflects the educators who are supposed to predominate the acquisition of listening skills by providing enough opportunities and 
sufficient exposure for the students to fall back from the issues they have been encountering. This study clearly shows listening skills and its' importance have been taken into consideration.

\section{Listening Skill Strategies}

Strategies are vital for one to learn or acquire something in an autonomous way. Learning or acquiring can occur in various ways, however, applying the right strategies in the classroom will enable the learners to learn a language better and in-depth. Utilizing correct strategies in learning, not only helps the learners to acquire the language better but also brings realization to the needs of the learners in acquiring the particular language. In short, strategies act as a guide to the learners' acquisition. For instance, Acevedo, Ochoa \& Obregon (2020), stated that the concept of cognitivism focuses on the stimulation of the learners' learning strategies. In line with it, cognitivism describes the idea that students process received information and reorganizes to gain new knowledge. Meanwhile, Ripoll (2021) argued that cognitivism builds on learners' prior knowledge and experience through a series of various activities and assessments. Therefore, in these two studies, researchers have mainly stated about the use of cognitivism in language and skill acquisition and this shows the importance of suitable strategies for learners' attainment. Learning strategies are important to all level learners to create a meaningful and sensible learning activity or process to take place. Strategies vary according to the skill and teachers play a crucial role in choosing, implementing, and developing suitable strategies in an ESL classroom to cater to the needs of the learners. Jeff (2016) has written a whole book on 7 classroom tips to be a highly effective teacher. The goal is to reflect, recognize and clarify the strength and weaknesses of an educator while teaching in an ESL classroom. An assessment instrument has been prepared to test the educators' performance level for an effective teaching process in a classroom. The first tip focuses on the framework for instruction and learning and ways to establish them in the classroom to achieve the teaching goals. It's also stated that a proficient lesson has matched lesson activities with the measurable objectives. Educators are highly responsible to create suitable activities or strategies about the needs and objectives. It's even more crucial when it involves the elementary learners as they're still fresh to be exposed to different types of learning strategies and the strategy should suit towards their inevitably to reach their goals.

Listening strategies have concepts that guide the learners towards reaching the goals of receiving input via hearing. A few researchers have given more importance to other skills than listening. However, Yavuz \& Celik (2017), it is not simple to exclude listening from language learning due to its vitality in communication. In a study carried out by Yildrim \& Yildrim (2016) listening takes up $40-50 \%$ of the time in communicating and the other skills which are speaking, reading, and writing comprise another $50 \%$ which is eventually less than the listening time taken. Various listening strategies can be carried out among primary learners in an ESL classroom. In a study carried out by Bao (2017), not many scholars have specialized in strategies related to studying listening skills. The empirical study resulted in a very small amount of strategies proposed by both educators and learners in terms of acquiring listening skills. The researcher has suggested that educators have to explore making certain teaching strategies cultivatable and intended for the learners. He further suggested that the dynamic process of learners' listening learning process should be tested in-depth to ensure the suitability in the quality and application of the listening strategies used. This is because the study resulted in the strategies educators instructed and learners utilized had a positive correlation with a little gap in its application level. Fatemah (2016) related the metacognitive 
awareness of listening strategies with listening strategy instruction and explicitness in her study. Pre and post-test were used to test the relational value between the two variables. Through the results obtained from those tests, it was claimed that learners had higher scores in their post-test after receiving explicit instructions of listening strategies. Therefore, explicit instruction gave a positive outcome towards the learners' metacognitive listening strategy awareness. In the end, the strategy applied has shown an adequate amount of increment in the respondents' results. The results proved that strategies should vary for the learners to get engaged, suit their needs, and easy for them to understand and apply in their learning.

\section{Listening Skill Issues}

As listening skill is one of the major skills, the educators need to deliver it appropriately using suitable strategies for their learners. However, there are a few factors that challenge the educators to deliver their lesson to make sure the acquisition of listening skills among the learners are perfect. Firstly, teachers may take listening skills as the most difficult skill to teach. There may be much reason to add to it but this leads learners not to experience the actual listening strategies to acquire the skill. Relatively, Feruza (2020) stated that an educator should be able to implement a variety of methods in the classroom to help the language learners to be out of boredom and demotivation. Methods that are used in listening comprehension are not only to foster listening skills but also the other skills in the language. She introduced a few effective listening strategies to foster listening skills among ESL learners which were the mock interview, authenticity, and technology applications. The study shows interesting methods should be encompassed with correct procedures to ensure learning stability among learners towards listening skills. In another context, Abbas and Narjes (2016) pointed out six major issues that learners face with listening comprehension skills. They started with the quality of recorded materials, followed by cultural differences, accent, unfamiliar vocabulary, length, and speed of listening. On the other hand, Ayatika Adawiyah (2017) ruled out certain listening issues among learners in her study. The issues rose were where the learners of young ages need something unusual but fun learning listening skill activities, learners had difficulty in understanding the meaning of words, learners' anxiety level when acquiring the skill and teachers' limitations. She proposed the use of popular songs as a medium of effective listening instruction. As result, the strategy was an ailment for the issues as the learners' interest in listening increased and the educator was able to deliver more opportunities for the learners. In short, issues may occur when attaining a particular knowledge especially in terms of listening skill in an ESL classroom among primary learners, yet the teacher and the instructions or the strategies implemented in the classroom plays a vital role in learners' level of acquisition.

\section{Methodology \\ Participants}

Participants were selected based on the convenience sampling method. Convenience sampling is a technique where a segment of the targeted population is used for a study. (Wilson \& Joye, 2016). Hence, the researchers included 30 participants from the one of the researchers' school in Johor Bahru district. All 30 participants consisted of Year 4 pupils (aged 10) from an intermediate level of proficiency. English language is the some of the participants' second language as all of them are from the Malay community. Purpose of using English language in their real life for the educational purpose merely. 


\section{Research Design}

The research design that was applied in this study was survey design. This quantitative method will be advantageous as it can be conducted with a set of standardized questions and it is an ideal method to ask about opinions and attitudes of a particular sample. (Nardi, 2018). Survey research design is a systematic procedure and useful tool used to collect, handle and analyze information (Laaksonen, 2018). Hence, to collect data, questionnaires were distributed among the selected 30 participants from a class of Year 4 of the participating school.

\section{Research Instruments}

The researchers referred Strategy Inventory for Language Learning (SILL) to make the questionnaire for this study. About 12 questions were adopted from SILL to focus on participants' listening strategy in the ESL classroom to enhance their listening skills. Besides, 5 Likert scale from the original questionnaire was adapted to 3 Likert scale; Scale 1: 'Never or almost never true of me', Scale 2: 'Somewhat true of me', and Scale 3: 'Always or almost always true of me'. The adaptation was made so that the participants would not get confused with the options given to select.

Classroom Observation was conducted to check on participants' change in behaviour while doing listening tasks in the classroom. The researcher randomly picked a lesson focusing on listening to conduct classroom observation. As for this, the researcher used a checklist tool namely Primary Listening Checklist by The Elementary Teachers' Federation of Ontario (ETFO). The checklist was used without any changes for the study. Participants' listening behaviours were observed by the researcher and recorded in the checklist by writing participants' names. Then, the researchers transferred the data into a table for data analysis.

\section{Data Analysis}

Each answer to the 12 items in the questionnaire and classroom observation checklist was awarded 1 point. The data collected from questionnaires and classroom observation were analyzed manually. The result from the questionnaire was assigned to a 'Never or almost never true of me', 'Somewhat true of me', and 'Always or almost always true of me'. As for classroom observation, the results were assigned to a rarely, sometimes, usually, and consistently. The scores gained from the collected data were calculated and tabulated according to focused items. The scores are shown in the following chapter: Findings and Discussion.

\section{Findings}

The mean for each of the six-language learning strategies for listening skill are listed in the table below. Based on the data collected through a Likert-scale questionnaire 1-3, the most common strategy used by the participants is social strategy, with a mean score of 2.65 .

\begin{tabular}{|l|l|}
\hline Language learning strategies & Mean \\
\hline Memory & 2.00 \\
\hline Cognitive & 2.02 \\
\hline
\end{tabular}




\begin{tabular}{|l|l|}
\hline Compensation & 1.93 \\
\hline Metacognitive & 1.57 \\
\hline Affective & 2.60 \\
\hline Social & 2.65 \\
\hline
\end{tabular}

Table 1: Language Learning Strategy with Mean Score

There are two questions asked on each language learning strategy. This is to ensure that the participants are clear with their choices and to keep the questionnaire short to suit the participants' age. Table 2 below shows the mean of both questions for social strategy.

\begin{tabular}{|l|l|}
\hline Question & Agree (\%) \\
\hline $\begin{array}{l}\text { I talk to someone else about how I feel when } \\
\text { I am learning SL. }\end{array}$ & 86.6 \\
\hline I practice SL with other students. & 76.6 \\
\hline
\end{tabular}

Table 2: Mean score for social strategy

Based on the table above, the mean for both questions are seem to be in high number. Participants were clearly able to choose the language learning strategy. For the first question, I talk to someone else about how I feel when I am learning SL, there were 26 participants that answered that they always do that with a percentage of 86.6. On the other hand, for the second question, I practice SL with other students, there were 23 pupils who answered that they always do that with a percentage of 76.6.

The bar graph below shows the ranking of language learning strategies used by the participants. The highest number of participants tend to use the social strategy, as mentioned earlier. Then, followed by affective strategy, memory strategy, congnitive strategy, compensation strategy and the least is metacognitive strategy to acquire listening skills in English language.

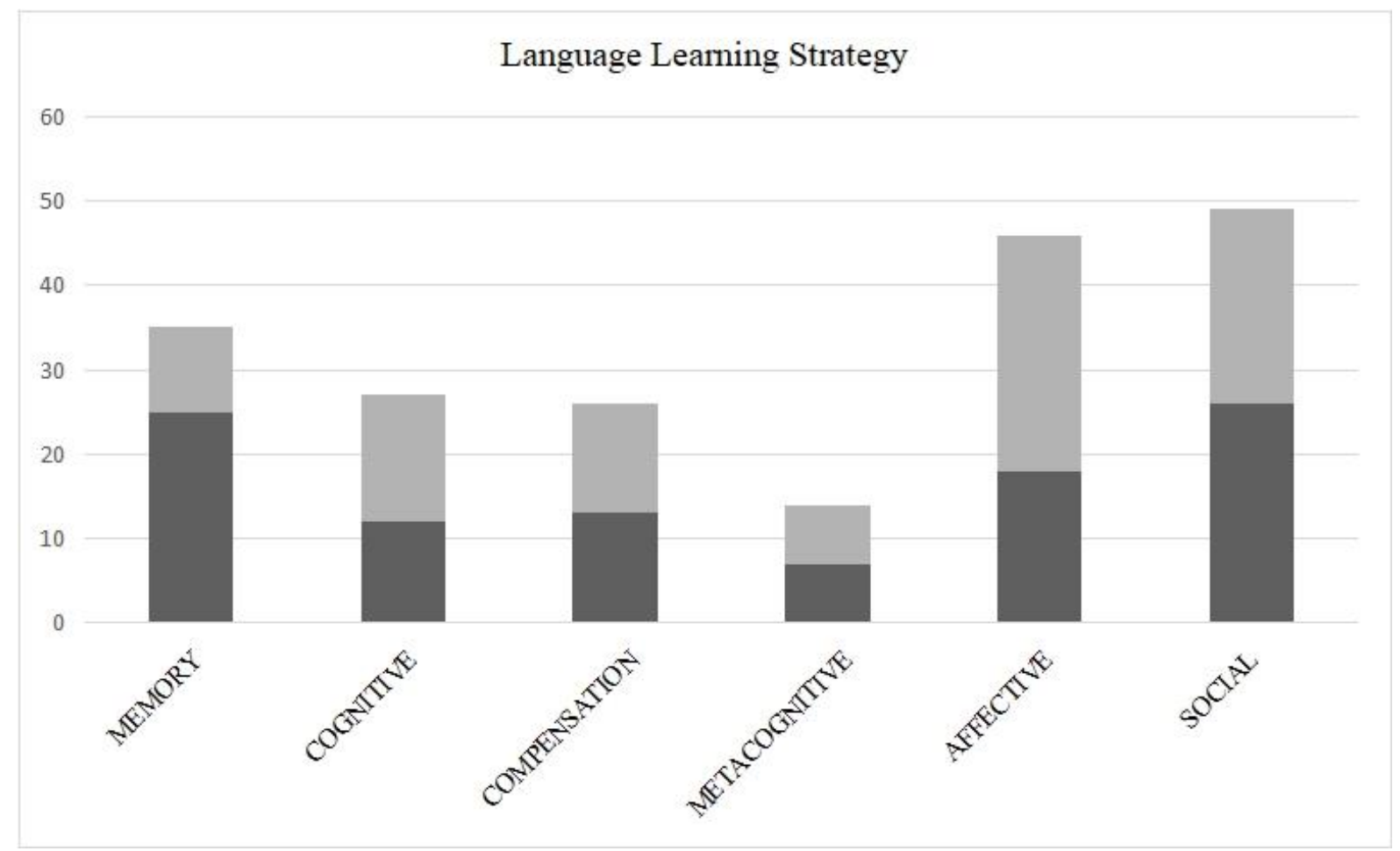

Graph 1: Questionnaire results 
The English teacher also used a checklist to test the listening competency among the research participants. The percentage of the listening competency among pupils is listed in the table below.

\begin{tabular}{|l|l|l|l|}
\hline Checklist & $\begin{array}{l}\text { Usually } \\
(\%)\end{array}$ & $\begin{array}{l}\text { Consistently } \\
(\%)\end{array}$ & $\begin{array}{l}\text { Total } \\
\text { (\%) }\end{array}$ \\
\hline Listens effectively one-to-one & 47 & 37 & 84 \\
\hline Listens effectively in small groups & 43 & 30 & 73 \\
\hline Recognizes classroom cues for listening & 23 & 33 & 56 \\
\hline Responds to cues to focus listening behaviour & 37 & 27 & 64 \\
\hline Identifies purpose for listening & 47 & 13 & 60 \\
\hline Listens effectively to follow instructions & 47 & 20 & 67 \\
\hline Listens effectively to a story & 60 & 23 & 83 \\
\hline Looks at the speaker when listening & 27 & 40 & 67 \\
\hline $\begin{array}{l}\text { Responds appropriately (nodding head, offering } \\
\text { comment or question) }\end{array}$ & 20 & 13 & 33 \\
\hline
\end{tabular}

Table 3: Percentage on criteria in checklist

Based on the table, it shows that majority of the participant, which is $84 \%$ of the pupils are listening effectively when the listening session is conducted one-to one. Participants are required to give individual attention when giving instructions to make them listen better. Next, $83 \%$ of participants enjoy listening to stories. Participants can be attentive when they are listening in a relaxed context.

\section{Discussion}

Based on the questionnaire data obtain, the highest number of pupils seem to use the social strategy as their language learning strategy in acquiring listening skills. This is because the pupils find it easier to learn the language by using it with their peers for interactions. Besides that, the pupils are also given a lot listening and speaking tasks in line with the current English language syllabus. This factor is believed to affect the pupils' language learning strategy for English language mainly focusing to listening skills. It is very important for the pupils to practice the language acquired for better understanding and usage of the language.

Besides that, there also high number of pupils who are seemed to choose the affective language learning strategy. When looked in detail, the research participants are all year 4 pupils, who are still considered as young learners. They are believed to be very sensitive emotionally. Their emotions when learning the language need to be taken into consideration so that the pupils will not get demotivated when learning the target language. Next in the list is memory strategy, followed by cognitive, compensation and metacognitive. Based on the bar graph, participants are believed to acquire the listening skills in English language through social and affective strategy.

On the other hand, through the checklist data obtained by the teacher of the participants, pupils can listen attentively when the conversation takes place between to people. When the teacher is communication individually with the pupils, they can listen well. The age of the pupils seems to be the factor where pupils find it hard to acquire all the information delivered by the teacher in a classroom setting with around 40 pupils. These points are proving that the teacher was needed to use the compensation strategy when teaching listening skills in the classroom. Teacher must help the pupils to understand and produce the target language by 
giving enough guidance individually. The teacher had to put more effort in helping the pupils to acquire listening skills.

Besides that, pupils are also seemed to listen effectively when the pupils are listening to a story. This shows that the pupils are into affective strategy. This is because, when listening to a story, the pupils' anxiety level is seen very low. Pupils are enjoying the listening activity during the story telling lesson. Therefore, pupils can listen effectively. The teacher was able to create a relaxed and fun learning environment during the storytelling session which eventually helped the pupils to acquire the listening skill in English language well.

Based on the study done, we can see that the most effective language learning strategy to acquire listening skills among the research participants is the affective language learning strategy. When the pupils were able to enjoy the listening lessons without stress and in an enjoyable setting pupil are seemed to listen effective. The point is seen both in the questionnaire result and in the checklist done by the teacher. The next strategy which is very effective among the participants are the compensation strategy and social strategy. It is crucial for the teacher to pay attention individually for the pupils to acquire the target language, besides giving the pupils situations to use the language among their friends in real life situations. Teacher plays an important role to ensure that these strategies are used in the classroom to help the pupils acquire the listening skills in English language effectively.

\section{Implications}

This study accentuates the use of listening strategies that are being used in the ESL classrooms. This specific area will acknowledge teachers across several discipline on the effectiveness of language learning strategies. This is because, speaking and listening are fundamental human communicative tools, and they have been our most basic and primal means of conveying messages since the dawn of time. No matter how smart the pupils are, they can only benefit from education if they develop sufficient listening skills in the classroom. Teachers usually give direct instructions and then provide explanations as needed but only pupils who listen carefully to the instructions can understand the conveyed message in the classroom. Effective classroom listening saves time and improves academic and social skills of the pupils. Research on language learning strategies focuses particularly on listening skill is essential to aid the pupils listening and understanding process. Therefore, language teachers must understand that focusing on one language learning strategy will never determine the pupil's understanding level. Pupils have their own way of learning, therefore, sticking into one strategy for all will never boost their understanding. Through planning, continuous practice and implementation of various listening strategies, language teachers can help their students to master strategic skills, develop autonomy and thus improve their listening skills.

Previous research has shown that pupils who use language learning strategies more often have a better chance of becoming more proficient language learners especially. It has been noted that more proficient learners will engage in a broader range of strategies and choose learning strategies based on the learning task or skills. Therefore, teachers are encouraged to implement a variety of listening strategies in their teaching and learning context so that learners will be able to choose the strategy that best suits their interest and is related to the learning task. In an English as a second language classroom context, the introduction of language learning strategy especially listening strategies are very important, for learners with low and average foreign language proficiency. It is vital to inspire learners to discover various ways to practice their listening skill and to find opportunities to participate in conversations with others. Learners who recognise the importance and use of language learning strategies 
can find new opportunities to practice their listening skill and improve their language proficiency.

\section{Conclusion}

This study has concluded that the most preferred language learning strategies used by the participants in this research is social strategy with the highest mean score of 2.65 . The second most preferred language learning strategy is the affective strategy with the mean score of 2.00. The data presented convinces that social strategy benefits learners when interacting with others in various situations. This strategy includes asking questions for clarification, cooperating with others, correcting, and developing understanding. Learners need this strategy to improve their speaking competencies. As for the affective strategy, it enables learners to monitor their emotions and thus gain their motivation to have positive attitudes during listening activities in the classroom. Good language learners often use positive statement to oneself when they face difficulties or problem while doing the listening tasks. On the other hand, the least preferred language learning strategy is the metacognitive strategy with the mean score of 1.57 . It is proven that the metacognitive strategy is not workable for the participants of this research. However, the results obtained should not be used to generalize student's perception on language learning strategies. In view of that fact, students in a mixed ability class may require more that one language learning strategy to enhance second language acquisition holistically. Thus, this calls for more wide research on this specific area to reach out to cater various needs.

\section{References}

Abbas, P. G., \& Narjes, B. S. (2016). Learners Listening Comprehension Difficulties in English Language Learning: A Literature Review. English Language Teaching. 9(6): 123132.

Acevedo, O., \& Obregon. (2020). Development of A New Educational Package Based on e-Learning to Study Engineering Thermodynamic Process: Combustion, Energy and Entropy Analysis. https://pdf.sciencedirectassets.com.

Ain Johar, N., \& Abdul Aziz, A. (2019). Teachers' Perceptions on Using the Pulse 2 textbook. Journal of Educational Research and Indigenous Studies, 2(1), 1-15.

Adawiyah, A. (2017). The Effectiveness of Popular Songs in Improving Students' Listening Skill. Faculty of Education Sciences. 5-132.

Berniger, A. (2017) Literacy builds life as well as language skills. New Straits Times. https://www.nytimes.com/2017/10/16/well/family/literacy-builds-lifeskills-as-well-as-language-skills.html

Djabborova, F. O. (2020). Ways of developing listening skills of English learners in ESL and EFL classroom. European Journal of Research and Reflection in Educational Sciences, 8(10), 212-216.

Farah, B. (2017). Towards Understanding Listening Comprehension in EFL Clasroom: The Case of the Saudi Learners. English Language Teaching. 10(6): 21-27.

Fatemah, Z. (2016). The Impact of Listening Strategy Training on the Meta-Cognitive Listening Strategies Awareness of Different Learner Types. English Language Teaching. 9(5): 154-165.

Feruza, A. E., \& Matluba, S. M. (2021). Improving English Language Listening Skill. Scientific Journal Impact Factor. 2(1): 28-32.

Feruza, O. D. (2020). Ways of Developing Listening Skills of English Learners in ESL and 
EFL Classroom. European Journal of Research and Reflection in Education Sciences. 8 (10): 212-216.

Graham, S., Santos, D., \& Francis-Brophy, E. (2014). Teacher beliefs about listening in a foreign language. Teaching and Teacher Education 40, 44-60.

Hashim, H. U., Yunus, M., \& Hashim, H. (2018). Language Learning Strategies used by Adult Learners of Teaching English as a Second Language (TESL). TESOL International Journal, 13(4), 38-48.

Jeff, C. M. (2016). The Highly Effective Teachers: 7 Classroom-Tested Practices That Foster Students Success. Alexandria, Virginia: ASCD.

Kasma, S. (2019). Use of Learning Strategies and their Effects on English Language Learning of Thai Adult Learners. The Southeast Asian Journal of English Language Studies. 25(4): 99-120

Khaled, M. S. M., \& Hussam, A. Q. (2020). Investigating Students' Attitudes Towards Listening and Speaking in the English Classroom at Al Istiqlal University: An Action Research. International Journal on Integrated Education. 3(8): 70-76.

Koksal, D., \& Ulum, O. G. (2016). Language Learning Strategies of Turkish and Arabic Students: A Cross-Cultural Study. European Journal of Foreign Language Teaching. 1(1): 123-143

Laaksonen, S. (2018). Survey Methodology and Missing Data. Springer.

Lee, H. F. (2017). A Look at The Relationship of Curiruculum and Instruction and the Art and Science of Teaching. Asian Journal and Education of Training. 3(2): 82-85.

Lingua, C. (2019). Listening the Primary Skill. https://listeninglinguacore

Nardi, P. M. (2018). Doing Survey Research: A Guide to Quantitative Methods. Routledge. Pourhosein, G. A., \& Sabouri, N. B. (2016). Learners' Listening Comprehension Difficulties in English Language Learning: A Literature Review. English Language Teaching. 9(6): 123-133.

Random, H. (2016). Random House Unabridged Dictionary. https://www.dictionary.com/browse/instruction.

Ripoll, V. (2021). Teaching Chemical Engineering to Biotechnology Students in the Time of COVID-19: Assessment of the Adaptation to Digitalization. Education For Chemical Engineers. 94-105.

Riri, F. (2016). An Investigation of English Listening Strategies. Indonesian Journal of Intergrated English Language Teaching. 2(1): 31-36

Shimma, M. H. (2017). Problems of Teaching the Listening Skill to Yemeni EFL Learners. International Journal of Scientific and Research Publications. 7(6): 140-148.

Tri, L. (2017). The Influence of Listening English Song to Improve Listening Skill in Listening Class. Journal of Multidisciplinary Studies. 1(1): 36-49.

Uri, N. F. M., \& Abd Aziz, M. S. (2018). Implementation of CEFR in Malaysia: Teachers' awareness and the Challenges. 3 L: Language, Linguistics, Literature ${ }^{\circledR}, 24(3)$.

Veenman, M. V. (2017). Learning to Self-Monitor and to Self-Regulate. Handbook of Research on Learning an Instruction. pp 233-257.

Wilson, J. H., \& Joye, S. W. (2016). Research Methods and Statistics: An Integrated Approach. SAGE Publications.

Yavuz, F., \& Celik, O. (2017). The Importance of Listening in Communication. Global Journal of Psychology Research: New Trends and Issues.7(1): 8-1.

Yildrim, S., \& Yildrim, O. (2016). The Importance of Listening in Language Learning and Listening Comprehension Problems Experienced by Language Learners: A Literature Review.16(4): 2094-2110. 
INTERNATIONAL JOURNAL OF ACADEMIC RESEARCH IN BUSINESS AND SOCIAL SCIENCES Vol. 11, No. 6, 2021, E-ISSN: 2222-6990 @ 2021 HRMARS 